\title{
An Overview of Fingerprint Patterns among Students of Gandaki Medical College, Pokhara, Nepal
}

\author{
Hirachan $\mathbf{N}^{1 *}$, Shrestha $\mathbf{R}^{2}$, Koju $\mathbf{S}^{2}$, Limbu $\mathrm{D}^{3}$ \\ 1 Lecturer, Forensic Medicine Department, ' 2 Lecturer, Anatomy Department, \\ Gandaki Medical College \& Teaching Hospital, Pokhara \\ ${ }^{3}$ Lecturer, Orthopedics Department, Karnali Academy of Health Sciences, Jumla, Nepal
}

\section{ABSTRACT}

Introduction: Fingerprint system of positive identification is based on the principle that the arrangement and distribution of fingerprint remains constant and persists throughout life and that the patterns of no two hands resemble each other.

Methods: A cross sectional study was carried out among 250 students (125 male and 125 female students), aged 17 - 40 years of age, of Gandaki Medical College, Pokhara, Nepal from 15 March to 13 April, 2017 A.D. The fingertip patterns of both hands were collected and identified with the aid of a magnifying glass and documented as: Loops, Whorls, Arches and Composite type. The data were enrolled in SPSS version 16 and analyzed accordingly.

Results: There was a preponderance of loop pattern (52.6\%) followed by whorls (39.4\%), arches (7.3\%) and composite $(0.6 \%)$. Whorls $(41.7 \%)$ were more common in males compared to females $(37.1 \%)$ and

\section{Keywords}

Fingerprint, Gender, Identification, Nepal.

\section{Corresponding author}

*Dr. Neelu Hirachan, MBBS, MD

Lecturer, Department of Forensic Medicine

Gandaki Medical College \& Teaching Hospital, Pokhara, Nepal

Email:drneeluhirachan@gmail.com females had more arches (9.6\%) compared to that of the male counterparts $(5.04 \%)$. There was no significant difference in fingerprint patterns among male and female students.

Conclusion: The predominance of loops amongst other fingerprint patterns along with no significant gender differences in fingerprint patterns can be considered as a valuable research finding in the field of forensic science.

\section{INTRODUCTION}

Fingerprint system of identification can be used as the most convenient, reliable and cheapest methods of positive identification. This method can be useful in identification in civil and criminal cases, especially in cases of decomposed, burnt, mutilated, dismembered body parts, mummified bodies etc ${ }^{1}$. Fingerprint system of identification is based on the principle that the skin of the balls of the fingers and thumbs is covered with characteristic ridges, the arrangement and distribution of which remains constant and persists throughout life and that the patterns of no two hands resemble each other. Even the fingerprints of the twins are not similar. It has been estimated that the chances of two persons having identical fingerprints is about one in 64 billion $^{2}$. By the application of comparison method of finger-prints at the scene of a crime with the finger-print record of suspected persons, investigators can establish absolute proof of the presence or identity of a person. This study of ridge pattern can also be applied to the skins of the palms and soles ${ }^{3}$. Sir Henry Galton (1892), depending on the arrangement of papillary ridges classified the finger-prints into four major types: Loop (65\%), Whorl (25\%), Arch (07\%) and Composite (0203\%). 
This study can be helpful to the forensic doctors, investigating police officers and other concerned authority engaged in the identification of cases in mass disaster, decomposed bodies, mutilated bodies etc. where preliminary gender identification can efficiently reduce their workload just by taking account of fingerprint pattern. The main objectives of our study were to find out the distribution of different fingerprint patterns among students of Gandaki Medical College, Pokhara, Nepal and to find out the differences in fingerprint patterns among male and female students of the same institute.

\section{METHODS}

This is a prospective cross sectional study which was carried out among 250 students, aged 17 - 40 years of age, of medical and paramedical fraternities of Gandaki Medical College, Lekhnath, Nepal over a period of one month from 15 March to 13 April, 2017 A.D ( $1^{\text {st }}$ Chaitra to $30^{\text {th }}$ Chaitra 2074). Firstly ethical clearance was obtained from the Institutional Ethics Review Committee Board (IERCB), Gandaki Medical College. Students with deformities and scars due to injuries, congenital abnormalities or diseases on their fingers or thumbs were excluded from the study. Materials used in this study were ink pad and magnifying glass. Before starting the procedure, informed expressed consent was taken after explanation of the whole procedure to each subject. Each participant was asked to wash his/her hands thoroughly. After drying of the hands, the subject was asked to press each finger on the stamp pad and then to transfer the ink-imprinted fingerprint by rolling the fingers over the respective fingerprint blocks made on A4 size paper format where other informations, e.g.; the name, sex and age of the participants had also been collected. The participants were made cautious not to double roll the fingers to prevent smudging of the print. The distribution of dermatoglyphic fingertip patterns of both hands were identified with the aid of a magnifying glass and documented as: Loops, Whorls, Arches and Composite type. The data were enrolled in SPSS version 16 and analyzed accordingly.

\section{RESULTS}

Fingerprint pattern analysis of 2500 fingers showed that the loops (52.6\%) were the most common fingerprint pattern followed by whorls (39.4\%), arches (7.3\%) and composite $(0.6 \%)$. Males had a higher incidence of whorls $(41.7 \%)$ compared to females $(37.1 \%)$ and females had more arches (9.6\%) compared to that of the male counterparts (5.04\%). Loops were found almost equivalent in both the population. Loops were mostly seen on little fingers (75.2\%) followed by middle fingers (64\%) and thumb (45.2\%). Whorls were more predominant on ring fingers $(58.2 \%)$ followed by thumb $(47.2 \%)$. Arches were more prevalent on index fingers $(15.6 \%)$ followed by middle finger (8.6\%).

There were significant differences in right thumb and right ring finger among male and female students $(\mathrm{p}<0.05)$. Except these two fingers, there was no significant difference in overall distribution of fingerprint pattern in both hands of male and female students $(p>0.05)$.

Table 1: Distribution of fingerprint patterns among male and female students of Gandaki Medical College

\begin{tabular}{clccc}
\hline $\begin{array}{c}\text { S. } \\
\text { No }\end{array}$ & Pattern & Males (\%) & Females (\%) & Total (\%) \\
1. & Loops & $657(52.6)$ & $659(52.7)$ & $1316(52.6)$ \\
2. & Whorls & $521(41.7)$ & $464((37.1)$ & $985(39.4)$ \\
3. & Arches & $63(5.04)$ & $120(9.6)$ & $183(7.3)$ \\
4 & Composite & $9(0.7)$ & $7(0.6)$ & $16(0.6)$ \\
& Total & $1250(50)$ & $1250(50)$ & $2500(100 \%)$ \\
\hline
\end{tabular}

Table 2: Distribution of fingerprint patterns in ten fingers of right and left hands among male and female students of Gandaki Medical College

\begin{tabular}{|c|c|c|c|c|c|c|c|c|c|}
\hline \multirow{2}{*}{$\begin{array}{l}\text { Fin- } \\
\text { gers }\end{array}$} & \multicolumn{4}{|c|}{ Males, N (\%) } & \multicolumn{4}{|c|}{ Females, $\mathbf{N}(\%)$} & \multirow[t]{2}{*}{$\begin{array}{l}\text { P.Val- } \\
\text { ue }\end{array}$} \\
\hline & Loop & Whorl & Arch & $\begin{array}{l}\text { Comp } \\
\text { osite }\end{array}$ & Loop & Whorl & Arch & $\begin{array}{l}\text { Com- } \\
\text { po } \\
\text { site }\end{array}$ & \\
\hline $\begin{array}{l}\text { Right } \\
\text { thumb }\end{array}$ & $\begin{array}{l}57 \\
(45.6 \%)\end{array}$ & $\begin{array}{l}66 \\
(52.8 \%)\end{array}$ & $\begin{array}{l}2 \\
(1.6 \%)\end{array}$ & $\begin{array}{l}00 \\
(0 \%)\end{array}$ & $\begin{array}{l}54 \\
(43.2 \%)\end{array}$ & $\begin{array}{l}59 \\
(47.2 \%)\end{array}$ & $\begin{array}{l}9 \\
(7.2 \%)\end{array}$ & $\begin{array}{l}3 \\
(2.4 \%)\end{array}$ & 0.048 \\
\hline $\begin{array}{l}\text { Right } \\
\text { index }\end{array}$ & $\begin{array}{l}52 \\
(41.6 \%)\end{array}$ & $\begin{array}{l}56 \\
(44.8 \%)\end{array}$ & $\begin{array}{l}16 \\
(12.8 \%)\end{array}$ & $\begin{array}{l}1 \\
(0.8 \%)\end{array}$ & $\begin{array}{l}52 \\
(41.6 \%)\end{array}$ & $\begin{array}{l}52 \\
(41.6 \%)\end{array}$ & $\begin{array}{l}21 \\
(16.8 \%)\end{array}$ & $\begin{array}{l}00 \\
(0 \%)\end{array}$ & 0.610 \\
\hline $\begin{array}{l}\text { Right } \\
\text { mid- } \\
\text { dle }\end{array}$ & $\begin{array}{l}85 \\
(68 \%)\end{array}$ & $\begin{array}{l}34 \\
(27.2 \%)\end{array}$ & $\begin{array}{l}6 \\
(4.8 \%)\end{array}$ & $\begin{array}{l}00 \\
(0 \%)\end{array}$ & $\begin{array}{l}86 \\
(68.8 \%)\end{array}$ & $\begin{array}{l}25 \\
(20 \%)\end{array}$ & $\begin{array}{l}14 \\
(11.2 \%)\end{array}$ & $\begin{array}{l}00 \\
(0 \%)\end{array}$ & 0.101 \\
\hline $\begin{array}{l}\text { Right } \\
\text { ring }\end{array}$ & $\begin{array}{l}38 \\
(30.4 \%)\end{array}$ & $\begin{array}{l}84 \\
(67.2 \%)\end{array}$ & $\begin{array}{l}1 \\
(0.8 \%)\end{array}$ & $\begin{array}{l}2 \\
(1.6 \%)\end{array}$ & $\begin{array}{l}52 \\
(41.6 \%)\end{array}$ & $\begin{array}{l}67 \\
(53.6 \%)\end{array}$ & $\begin{array}{l}6 \\
(4.8 \%)\end{array}$ & $\begin{array}{l}00 \\
(0 \%)\end{array}$ & 0.022 \\
\hline $\begin{array}{l}\text { Right } \\
\text { little }\end{array}$ & $\begin{array}{l}87 \\
(69.6 \%)\end{array}$ & $\begin{array}{l}37 \\
(29.6 \%)\end{array}$ & $\begin{array}{l}1 \\
(0.8 \%)\end{array}$ & $\begin{array}{l}00 \\
(0 \%)\end{array}$ & $\begin{array}{l}92 \\
(73.6 \%)\end{array}$ & $\begin{array}{l}28 \\
(22.4 \%)\end{array}$ & $\begin{array}{l}5 \\
(4 \%)\end{array}$ & $\begin{array}{l}00 \\
(0 \%)\end{array}$ & 0.132 \\
\hline $\begin{array}{l}\text { Left } \\
\text { thumb }\end{array}$ & $\begin{array}{l}57 \\
(45.6 \%)\end{array}$ & $\begin{array}{l}59 \\
(47.2 \%)\end{array}$ & $\begin{array}{l}6 \\
(4.8 \%)\end{array}$ & $\begin{array}{l}3 \\
(2.4 \%)\end{array}$ & $\begin{array}{l}58 \\
(46.4 \%)\end{array}$ & $\begin{array}{l}52 \\
(41.6 \%)\end{array}$ & $\begin{array}{l}13 \\
(10.4 \%)\end{array}$ & $\begin{array}{l}2 \\
(1.6 \%)\end{array}$ & 0.358 \\
\hline $\begin{array}{l}\text { Left } \\
\text { index }\end{array}$ & $\begin{array}{l}54 \\
(43.2 \%)\end{array}$ & $\begin{array}{l}54 \\
(43.2 \%)\end{array}$ & $\begin{array}{l}17 \\
(13.6 \%)\end{array}$ & $\begin{array}{l}00 \\
(0 \%)\end{array}$ & $\begin{array}{l}48 \\
(38.4 \%)\end{array}$ & $\begin{array}{l}52 \\
(41.6 \%)\end{array}$ & $\begin{array}{l}24 \\
(19.2 \%)\end{array}$ & $\begin{array}{l}1 \\
(0.8 \%)\end{array}$ & 0.46 \\
\hline $\begin{array}{l}\text { Left } \\
\text { mid- } \\
\text { dle }\end{array}$ & $\begin{array}{l}76 \\
(60.8 \%)\end{array}$ & $\begin{array}{l}39 \\
(31.2 \%)\end{array}$ & $\begin{array}{l}7 \\
(5.6 \%)\end{array}$ & $\begin{array}{l}3 \\
(2.4 \%)\end{array}$ & $\begin{array}{l}73 \\
(58.4 \%)\end{array}$ & $\begin{array}{l}35 \\
(28 \%)\end{array}$ & $\begin{array}{l}16 \\
(12.8 \%)\end{array}$ & $\begin{array}{l}1 \\
(0.8 \%)\end{array}$ & 0.187 \\
\hline
\end{tabular}




\begin{tabular}{llllllllll} 
Left & 53 & 67 & 5 & 00 & 45 & 73 & 7 & 00 & 0.537 \\
ring & $(42.4 \%)$ & $(53.6 \%)$ & $(4 \%)$ & $(0 \%)$ & $(36 \%)$ & $(58.4 \%)$ & $(5.6 \%)$ & $(0 \%)$ & \\
Left & 98 & 25 & 2 & 00 & 99 & 21 & 5 & 00 & 0.441 \\
little & $(78.4 \%)$ & $(20 \%)$ & $(1.6 \%)$ & $(0 \%)$ & $(79.2 \%)$ & $(16.8 \%)$ & $(4 \%)$ & $(0 \%)$ & \\
\hline
\end{tabular}

\section{DISCUSSION}

This study found that the predominance of loops with $52.6 \%$ (1316 out of 2500 responses) followed by whorl with $39.4 \%$ (985 out of 2500 responses, arch with $7.3 \%$ (183 out of 2500 responses) and composite with $0.6 \%$ (16 out of 2500 responses) in our study is in accordance with other studies involving medical students ${ }^{4-10}$. Percentage of loops found, were lower simultaneously with increased percentage of whorls while comparing with worldwide distribution percentage ${ }^{5-10}$. Our findings of loops $(52.6 \%$ in males and $52.7 \%$ in females) is dissimilar when compared with the varied results given by Katwal et al and Kumar KR et al where there is male preponderance and Karki et $a l$, Rastogi et al, Mehta et al where loop is predominant in female students. Our finding of whorl more predominant in male population is similar to the ones given by Karki et al and Mehta et al. Arches more prevalent in female students (9.6\%) compared to $5.04 \%$ of male students is similar to that of findings given by Karki et al, Rastogi et al, Barsika et al and Kumar KR et al. Loops were found commonly in little fingers (75.2\%) which was a similar figure to that given by Katwal et al (75.5\%) and Kumar KR et al (76\%). Loop occurrence in our study was followed by middle finger $(64 \%)$ and thumb $(45.2 \%)$ which was similar to findings given by researchers in their study ${ }^{9,10}$. Whorls were common in ring finger (58.2\%) followed by thumb (47.2\%) and index finger (42.8\%) in our study with similar findings in studies done by these researchers ${ }^{4,8-10}$. Arches in our study were common in index finger (15.6\%) and middle finger (8.6\%) which were similar to $12.5 \%$ and $7.75 \%$ found in index finger and middle finger by Katwal et al in her study and $12.2 \%$ occurrence of arches in middle finger in study done by Kumar KR et al. Beside the right thumb and the right ring fingers, there was not any significant difference in overall distribution of fingerprint pattern in both hands among males and females which was similar conclusion as given by Kanchan et $a l^{4}$, Rastogi et $a l^{7}$, Mehta et $a l^{8}$, Katwal et $a l^{9}$ and Kumar KR et $a l^{10}$.

\section{CONCLUSIONS}

The predominance of loops amongst other fingerprint patterns along with no significant gender differences in fingerprint patterns can be considered as a valuable research finding in the field of forensic science.

\section{REFERENCES}

1. Chapman AJ. Death and Deduction. $2^{\text {nd }}$ ed. Kathmandu 2007; 300-308.

2. Vij K. Textbook of Forensic Medicine and Toxicology Principles and Practice. 4th ed. India: Elsevier, 2008; 76-77.

3. Rao N.G. Textbook of Forensic Medicine and Toxicology. 2nd ed. Jaypee Brothers Medical Publishers (P) Ltd. 2010; 115-116.

4. Kanchan T, Chattopadhyay S. Distribution of Fingerprint Patterns among Medical Students. Journal of Indian Acad of Forensic Med. 2006; 28(2): 65-68.

5. Bharadwaja A., Saraswat P.K., Agrawal S.K., Banerji P. and Bharadwaj S. Pattern of fingerprints in different $\mathrm{ABO}$ blood groups. Journal of Forensic medicine \& Toxicology. 2004; 21(2): 49- 52.

6. Karki RK, Singh PK. Gender determination from fingerprints. J Universal Coll Med Sci. 2014; 2: 1.

7. Prateek Rastogi, Keerthi R Pillai. A study of finger print in relation to gender and blood group. JIAFM. 2010; 32(1): 11-13.

8. Amit AM, Anjulika AM. Study of fingerprint patterns among medical students in Vidarbha Region, India. Int J Anat Res. 2015; 3(2): 10431045.

9. Katwal B, Timsinha S, Limbu BK, Pant PP. Fingerprint analysis and gender predilection among medical students of Nepal Medical College and Teaching Hospital. International Journal of Research \& Review. 2017; 4(7): 62-66.

10. Arun Kumar KR, Manoranjitham R, Shalini R, Ravivarman C. Study of fingerprint patterns among medical students. Int J Anat Res. 2016; Vol 4(2): 2273-76. 